\title{
Design of Solar Tricycle for Handicapped Person
}

\author{
${ }^{1}$ Ravikumar Kandasamy, ${ }^{2}$ Sachin Raut, ${ }^{3}$ Deep Varma, ${ }^{4}$ Ganesh There \\ ${ }^{I}$ Deputy director, MGIRI, Wardha \\ ${ }^{2} \mathrm{SSO}$, MGIRI, Wardha \\ ${ }^{3}$ Principle Scientific Officer, MGIRI,Wardha (M.S.) \\ ${ }^{4}$ Pursuing M.E. (by research) in BDCOE,Sevagram (MS), Technical assistant in MGIRI Wardha
}

\begin{abstract}
Solar plays a vital role in our day to day life. We have developed the solar tricycle especially for handicapped person of ANANDVAN organization started by Mr. Baba Amate in Warora taluka of Maharashtra state (India). The organization is working for the leprosy affected people. In this paper it is discussed that how solar tricycle will help to reduce the effort of handicapped person. All the designs specification considered after analyzing the problems from the handicapped person. Comfort of the person in the tricycle is an important and we have given importance to it. The main content of the tricycle is Solar PV panel, Brushless PMDC motor, Charge controller and battery. This paper will discuss about the main idea of this project and to get a larger picture on what is the problem in the current technologies, what that I want to achieve in this project and the area that will cover on this project. This paper is divided into some categories that are project background to describe the reasons to do this project, problem statement to inform about the problem or weakness of the existing technology, objective to make sure what actually this project must achieve and scope of this project to specify what will be used in this project.
\end{abstract}

\section{Introduction}

Electric vehicles, which use $100 \%$ electric power, use electric motors instead of an internal combustion engine to provide motive force. Solar-powered vehicles (SPVs) use photovoltaic (PV) cells to convert sunlight into electricity. The electricity goes either directly to an electric motor powering the vehicle, or to a special storage battery. PV cells produce electricity only when the sun is shining. Without sunlight, a solarpowered car depends on electricity stored in its batteries.

Since the 1970s, inventors, government, and industry have helped to develop solar-powered cars, boats, bicycles, and even airplanes. In 1974, two brothers, Robert and Roland Boucher, flew an extremely lightweight, remote-controlled, pilotless aircraft to a height of 300 feet. It was powered by a PVarray on the wings. (The U.S. Air Force funded the development of these aircraft with the hope of using them as spy planes.) The first totally solar-powered car was built in 1977. It was small, lightweight, and cost relatively little. Experimental SPV's, equipped with advanced technology, have been built with the backing of major auto manufacturers, including General Motors, Ford, and Honda.

There will be a big area at the agi campus wardha when it is fully built and operates. So students need a vehicle to move from one side to another. In state of using car or motorcycle that are costly, student will be prefer to used tricycle as their vehicle. There several types of tricycle that can be chosen such as paddle tricycle, motorized tricycle and electric tricycle. But there are some weaknesses about that type of tricycle. To overcome the weakness this project will develop a better tricycle. Because of India is located in the topic of Capricorn area, this project will make used the energy of the sun that rarely used in India to generate the tricycle.

As what had been mention earlier, there are several types of tricycle that can be categories that is paddle tricycle, motorized tricycle, and electric tricycle. The weakness of the tricycle make people do not like to used tricycle. First, paddle tricycle needs a lot of energy to paddle the tricycle. The user will surely be tired after used the tricycle. This will not suitable for student to use to go to the class because they will be tired when they are in the class and will lost their concentration while hearing the lecture. Next, motorize tricycle that used fuel as it prime mover. The tricycle use fuel that is costly. As a student, their allowance is limited and only can be used for their study material and for their food to survive at the campus. Besides that, motorize tricycle will make pollution that can be very bad for our environment especially in this period that global warming happen to the earth. Lastly, electric tricycle that generate by battery can be only be sufficient for about an hour. The user needs to find power supply to recharge the battery or else they need to paddle the tricycle that used more energy compare to the normal tricycle because of the weight.

\section{Objectives}

To overcome the problem and the weakness, this project need to do some research and studying to develop better technology. To make it success there are several thing that we need to know such as what will be 
the prime mover, how to stored it and the advantages of this new vehicle. In that case, these are the list of the objective to be conduct before continue to proceed on this project:

- To develop a vehicle that use renewable energy, environmentally friendly and cheap.

- To develop an electrical tricycle that can charge the battery when it is not in used.

- To develop low speed tricycle, but for a longer distance.

\section{Organization of the project}

Since the we have visited to the Anandavan, warora which is located in chandrapur District. The owner of the anandvan is sociologist baba amte. In the anandvan all type of physically handicapped person are lived and they are using manual operated tricycle. We are watching the most weakness physical handicapped person difficult to operate the tricycle. We think on the tricycle how would become easily operated by the aged person. In this way the

\section{Idea comes in our mind.}

Basically in India tricycle mostly used only the handicapped person. But in foreign country tricycle as the handicapped person is used as well as the non handicapped person is used.

\section{Scope of Hybrid solar tricycle}

- To convert the solar energy to the electrical energy by using solar cells, then Converting this electrical energy to mechanical energy by using dc motor to run the tricycle beside the human paddling.

- To find the alternative of fuel.

- To maintain the ecological balance.

- To form the economical tricycle.

- There is a need for a green energy.

\subsection{Introduction}

\section{Literature Review And Theory}

In order to perform this project, literature review has been made from various sources like journal, books, article and others. This chapter includes all important studies which have been done previously by other research work. It is importance to do the literature review before doing the project because we can implement if there are information that related to this project. The most important thing before starting the project we must clearly understand about the topic that we want to do. So by doing the literature review we can gain knowledge to make sure we fully understand and can complete the project. A review of the article was performed to identify studies that relevant to the topic. The search to find material that related to the topic is categories as solar panel, solar charger, battery, motor, electric tricycle and speed control.

\subsection{Literature review}

\section{a. Solar panel}

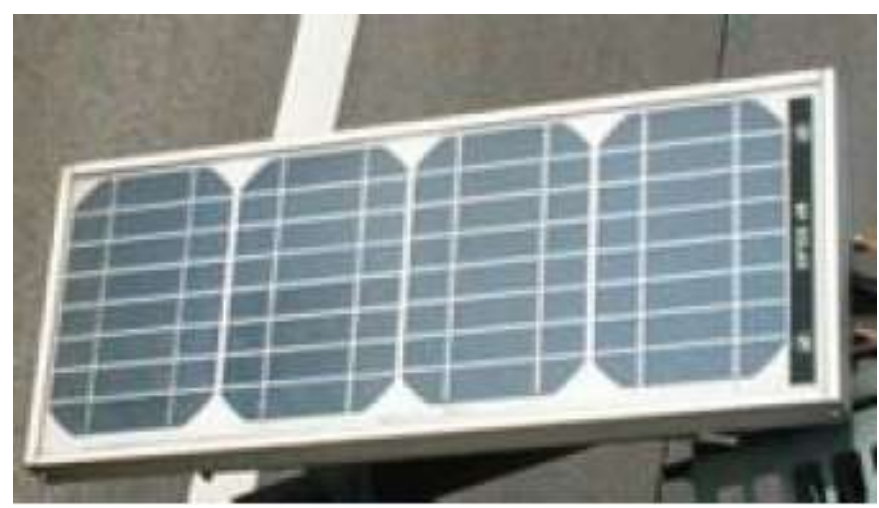

Figure 1: solar panel

A photovoltaic module or photovoltaic panel is a packaged interconnected assembly of photovoltaic cells, also known as solar cells. The photovoltaic module, known more commonly as the solar panel, is then used as a component in a larger photovoltaic system to offer electricity for commercial and residential applications. The primary difficulty with solar power and indeed with its cousin wind power has been one of efficiency. There is more than enough energy hitting the earth in the form of solar radiation to meet power needs of our species. Estimates indicatethat there is four times as much wind energy available for our use as the species uses every year. Solar power is even more dramatic, the sun showers the planet with more energy every day than we use in a year. So the difficulty has never been the availability of sun and wind, they are readily available. 


\section{b. Solar charge controller}

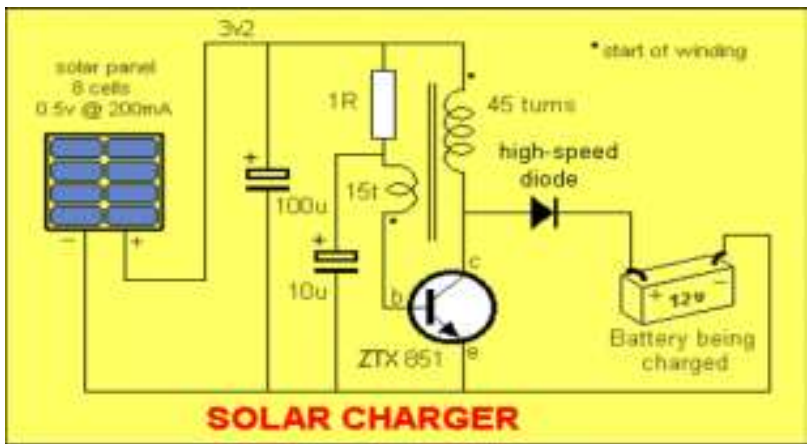

Figure 2 Circuit diagram for solar charger.

Solar battery chargers are an inexpensive, environmentally friendly, and convenient way to make sure your batteries are always fully charged and ready to go all the time. The problem with charging a battery from a solar panel is the Sun. It does not shine all the time and clouds get in the way. Our eyes adjust to the variations in the strength of the sun but a solar panel behaves differently. As soon as the sun loses its intensity, the output from a solar panel drops enormously. Not only does the output current fall, but the output voltage also decreases. Many of the solar panels drop to below the $13.6 \mathrm{v}$ needed to charge a $12 \mathrm{v}$ battery and as soon as this occurs, the charging current drops to ZERO. This means they become useless as soon as the brightness of the sun goes away

\section{c. Battery}

Given the current market, lead-acid is the only viable battery technology for electric vehicle conversion. The following is a list of criteria to use in selecting an electric vehicle battery.

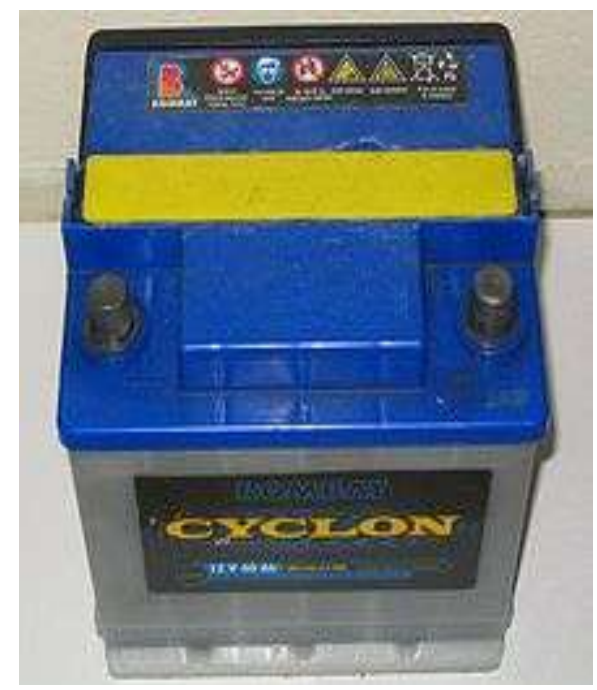

Figure 3: Battery

1. Voltage. Batteries are available in both $6 \mathrm{~V}$ and $12 \mathrm{~V}$ units. Most standard, wet-cell, golf cart batteries are $6 \mathrm{~V}$ units. Most sealed batteries are $12 \mathrm{~V}$ units.

2. Amp-hour rating. The capacity of a battery is rated in amp-hours. This rating must be specified with a given discharge rate.

3. Discharge rate. The discharge rate of a battery is the minimum length of time during which the battery must be discharged in order to meet the specified amp hour rating.

4. Watt-hour rating. The watt-hour rating is a true indication of the energy Capacity of a battery, like the amphour rating, this rating must be specified with a discharge rate. The watt-hour rating of a battery is the amp-hour rating multiplied by the specified voltage of the battery.

5. Energy density. Energy density is the energy capacity of the battery, in watt-hours, divided by the weight of the battery, in kilograms. This is a critical factor in selecting an electric vehicle battery-the amount of energy a battery carries per unit weight.

6. Cycle-life. Cycle-life is the number of times a battery can be fully discharged before replacement. However, in most real applications, a lead-acid battery will exceed its specified cycle-life, since the battery will not be fully discharged every time it is used. 


\section{Design And Description}

The title of the project may be lead, because it going to be easy fabricating a full sized solar tricycle. It is not only difficult but also very costly. So it is better to do this as a project which includes lots of study and then a demonstration of how the solar energy can be converted and stored in batteries and then how it can be used to run the vehicle. May be with the staffs permission you may be able to use your college's water heater solar panel if there is any. The project includes lots of calculations on how much energy can be stored, how fast the energy can be stored, how maximum efficiency can be achieved etc.

The solar powering system of the tricycle consists of:

1. Solar Array which collects solar energy and convert it to electrical energy

2. Power trackers to achieve the proper voltage to be stored in batteries.

3. Batteries to stir power.

4. Motor controller which adjusts the power input to the motor.

5. An electric motor which drives the vehicle

\subsection{Solar panel}

Photovoltaic's is the field of technology and research related to the devices which directly convert sunlight into electricity. The solar cell is the elementary building block of the photovoltaic technology. Solar cells are made of semiconductor materials, such as silicon. One of the properties of semiconductors that makes them most useful is that their conductivity may easily be modified by introducing impurities into their crystal lattice. For instance, in the fabrication of a photovoltaic solar cell, silicon, which has four valence electrons, is treated to increase its conductivity. On one side of the cell, the impurities, which are phosphorus atoms with five valence electrons (n-donor), donate weakly bound valence electrons to the silicon material, creating excess negative charge carriers. On the other side, atoms of boron with three valence electrons ( $\mathrm{p}$-donor) create a greater affinity than silicon to attract electrons. Because the-type silicon is in intimate contact with the n-type silicone p-n junction is established and a diffusion of electrons occurs from the region of high electron concentration (the $\mathrm{n}$ type side) into the region of low electron concentration (p-type side). When the electrons diffuse across the $p-n$ junction, they recombine with holes on the p-type side. However, the diffusion of carriers does not occur indefinitely, because the imbalance of charge immediately on either sides of the junction originates an electric field. This electric field forms a diode that promotes current to flow in only one direction. Ohm metalsemiconductor contacts are made to both the n-type and p-type sides of the solar cell, and the electrodes are ready to be connected to an external load. When photons of light fall on the cell, they transfer their energy to the charge carriers. The electric field across the junction separates photo-generated positive charge carriers (holes) from their negative counterpart (electrons). In this way an electrical current is extracted once the circuit is closed on an external load. There are several types of solar cells. However, more than $90 \%$ of the solar cells currently made worldwide consist of wafer-based silicon cells. They are either cut from a single crystal rod or from a block composed of many crystals and are correspondingly called mono-crystalline or multi-crystalline silicon solar cells. Wafer-based silicon solar cells are approximately $200 \mu \mathrm{m}$ thick. Another important family of solar cells is based on thin-films, which are approximately $1-2 \mu \mathrm{m}$ thick and therefore require significantly less active, semiconducting material. Thin-film solar cells can be manufactured at lower cost in large production quantities; hence their market share will likely increase in the future. However, they indicate lower efficiencies than waferbased silicon solar cells, which means that more exposure

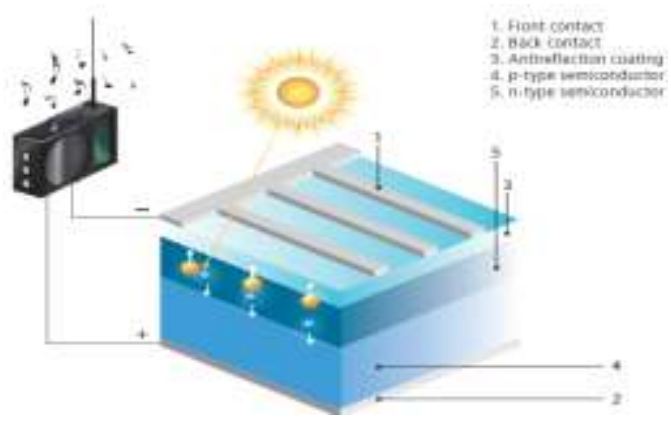

A number of solar cells electrically connected to each other and mounted in a single support structure or frame is called a 'photovoltaic module'. Modules are designed to supply electricity at a certain voltage, such as a common 12 volt system. The current produced is directly dependent on the intensity of light reaching the module. Several modules can be wired together to form an array. Photovoltaic modules and arrays produce direct-current electricity. They can be connected in both series and parallel electrical arrangements to produce any required voltage and current combination. There are two main types of photovoltaic system. Grid connected 
systems (on-grid systems) are connected to the grid and inject the electricity into the grid. For this reason; the direct current produced by the solar modules is converted into a grid-compatible alternating current. However, solar power plants can also be operated without the grid and are then called autonomous systems (off-grid systems). More than $90 \%$ of photovoltaic systems worldwide are currently implemented as grid-connected systems. The power conditioning unit also monitors

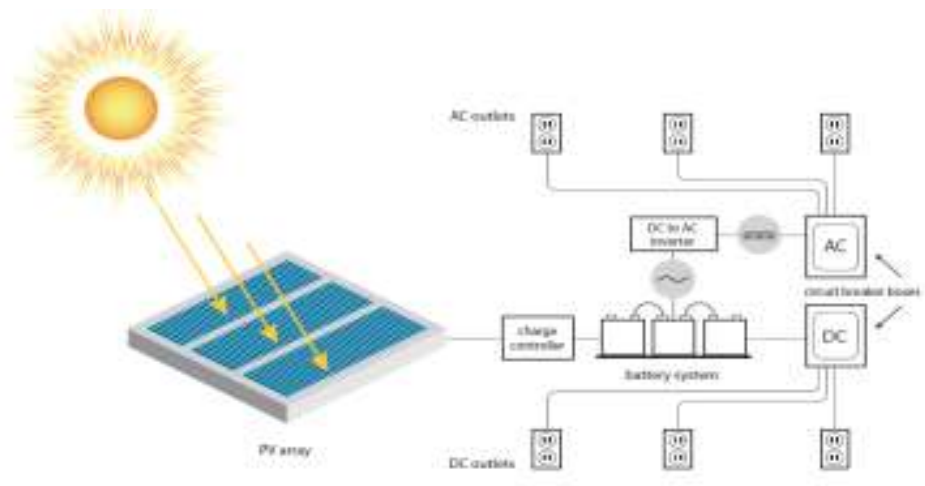

the functioning of the system and the grid and switches off the system in case of faults. working of solar panel

\subsection{DC motor}

A DC motor is an electric motor that runs on direct current (DC) electricity

There are two type of dc motor

- Brushed DC electric motor

- Brushless DC electric motor

- Uncommutated

\section{Brushed DC electric motor}

The brushed DC electric motor generates torque directly from DC power supplied to the motor by using internal commutation, stationary permanent or electromagnets, and

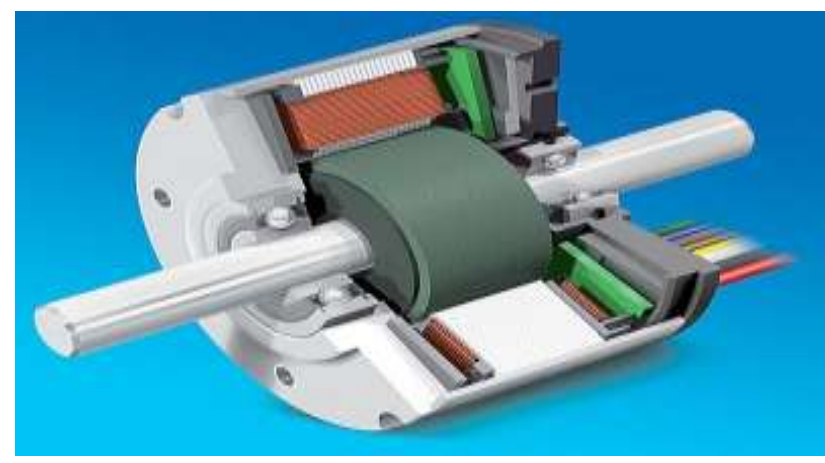

rotating electrical magnets.

\section{Brushed de motor}

Like all electric motors or generators, torque is produced by the principle of Lorentz force, which states that any current-carrying conductor placed within an external magnetic field experiences a torque or force known as Lorentz force. Advantages of a brushed DC motor include low initial cost, high reliability, and simple control of motor speed. Disadvantages are high maintenance and low life-span for high intensity uses. Maintenance involves regularly replacing the brushes and springs which carry the electric current, as well as cleaning or replacing the commutated. These components are necessary for transferring electrical power from outside the motor to the spinning wire windings of the rotor inside the motor.

\section{Brushless}

Brushless DC motors use a rotating permanent magnet or soft magnetic core in the rotor, and stationary electrical magnets on the motor housing. A motor controller converts DC to AC. This design is simpler than that of brushed motors because it eliminates the complication of transferring power from outside the motor to the 
spinning rotor. Advantages of brushless motors include long life span, little or no maintenance, and high efficiency. Disadvantages include high initial cost, and more

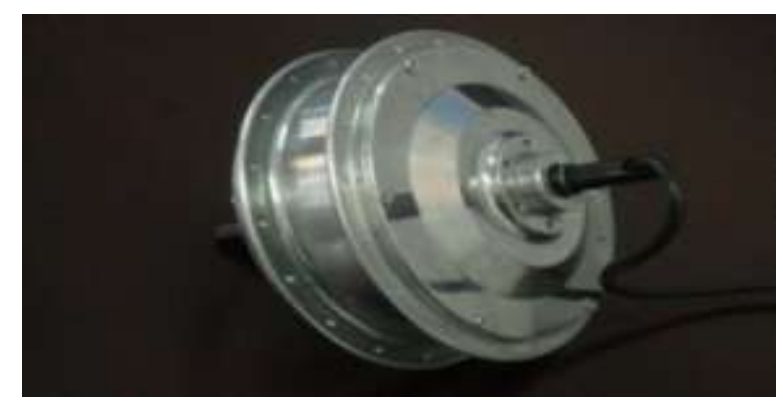

\section{Brushless de motor}

Brushless dc motor complicated motor speed controllers. Some such brushless motors are sometimes referred to as "synchronous motors" although they have no external power supply to be synchronized with, as would be the case with normal AC synchronous motors.

\section{Uncommutated}

Other types of DC motors require no commutation.

- Homopolar motor - A homopolar motor has a magnetic field along the axis of rotation and an electric current that at some point is not parallel to the magnetic field. The name homopolar refers to the absence of polarity change. Homopolar motors necessarily have a single-turn coil, which limits them to very low voltages. This has restricted the practical application of this type of motor.

- Ball bearing motor - A ball bearing motor is an unusual electric motor that consists of two ball bearingtype bearings, with the inner races mounted on a common conductive shaft, and the outer races connected to a high current, low voltage power supply. An alternative construction fits the outer races inside a metal tube, while the inner races are mounted on a shaft with a non-conductive section (e.g. two sleeves on an insulating rod). This method has the advantage that the tube will act as a flywheel. The direction of rotation is determined by the initial spin which is usually required to get it going.

\subsection{Battery}

A system which converts chemical energy into electrical energy More correctly, a battery is an electrochemical cell: Galvanic Cells convert the energy from spontaneous chemical reactions into electricity Electrolytic Cells use electricity to drive non-spontaneous chemical reactions All galvanic cells produce electricity from reactions which involve the transfer of electrons from one species to another There are two components to each cell - the species donating the electrons, and the species accepting them We write "halfreactions" to represent these two components, and to explicitly show the transfer of electrons The oxidation half-reaction shows the species which is donating electrons The reduction half-reaction show the species which is receiving electrons We can also write the net reaction (or overall reaction) for the cell, the balanced sum of the two half-reactions

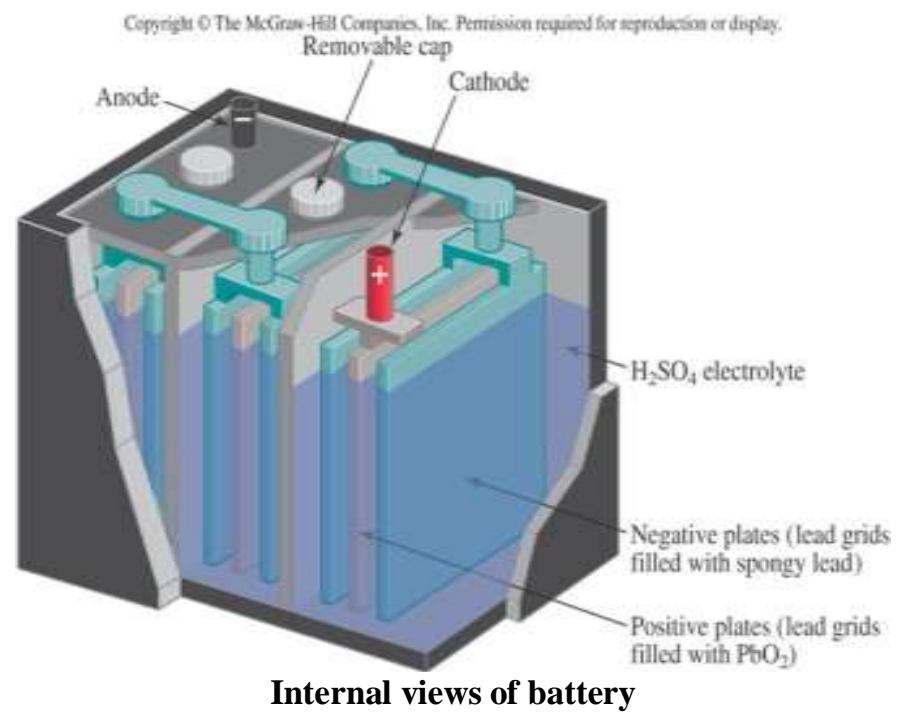




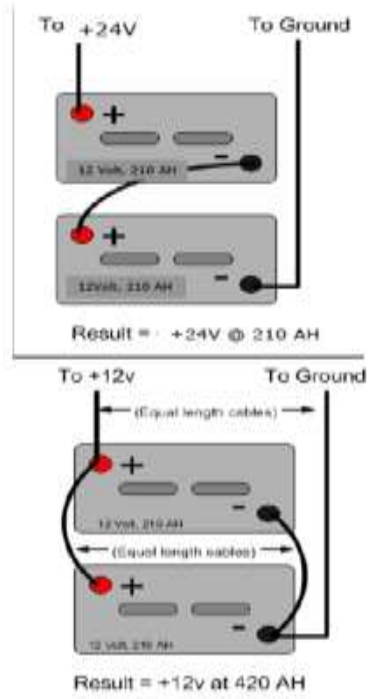

Series and parell conection of battery

\section{Specifications:}

- Solar panel: 12 volt, $75 \mathrm{~W}=2$ Nos.

- Motor:, brushless de motor, 24 volt, Maximum load current is. Power rating is $250 \mathrm{~W}, 300 \mathrm{rpm}$.

- Battery: 12 V- 2 Nos.

- Charging time: $6 \mathrm{hr}$

- Maximum speed: $33 \mathrm{~km} / \mathrm{hr}$

- Frame: Steel in parts with high strength requirements.

- Wheels: Front $20 \times 1.75$. Rear $23 \times 2.00$.

- Tyres: Front 23 x 2.50. Rear 20 x $2.00 / 2.25$ moped strength.

- Size: Length $2.3 \mathrm{M}$. Width - $1.2 \mathrm{M}$.

- Weight: Chassis $98 \mathrm{Kg}$.

- Load Capacity: $90 \mathrm{~kg}$

- Handlebars: Maxims Design.
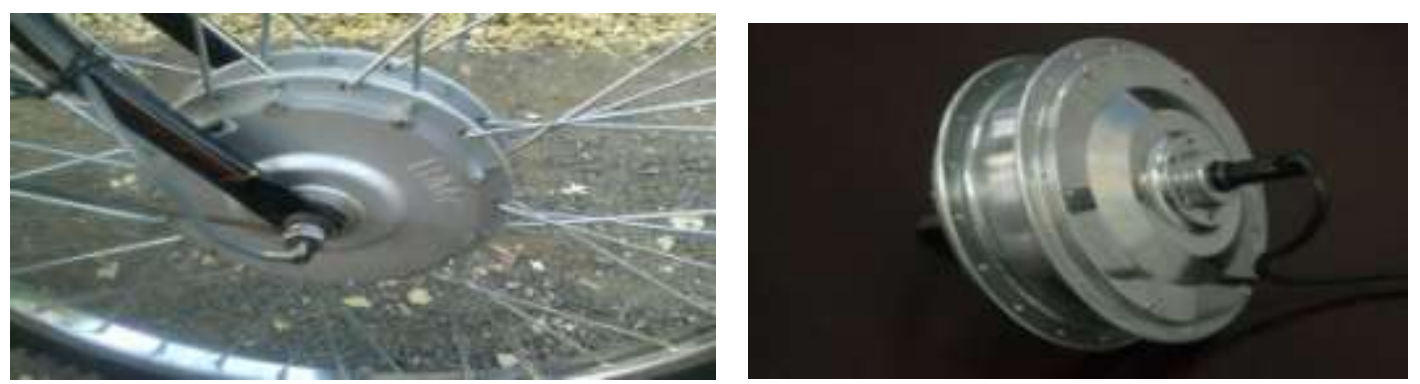

Breshless dc motor

Brushless DC motor mounted on wheel

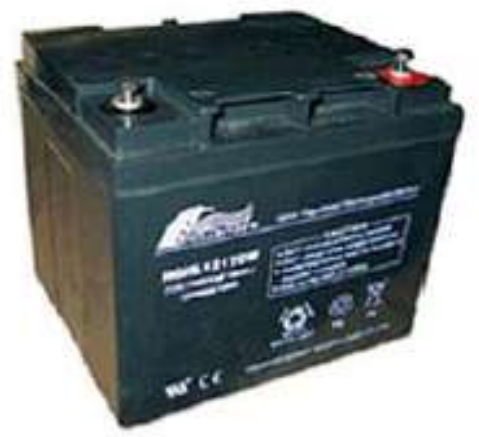

Battery 


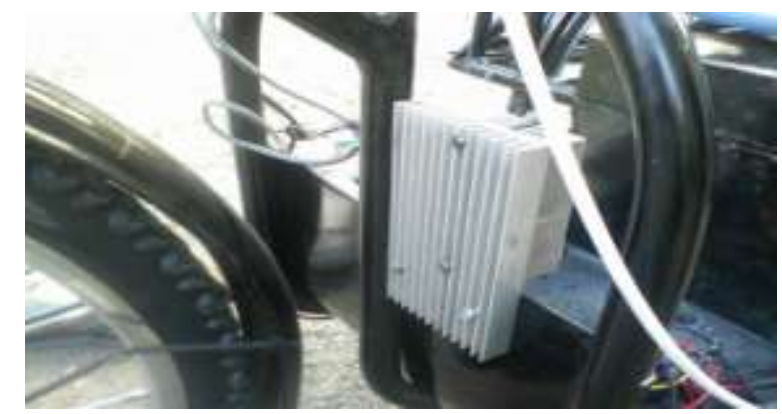

Heat exchanger

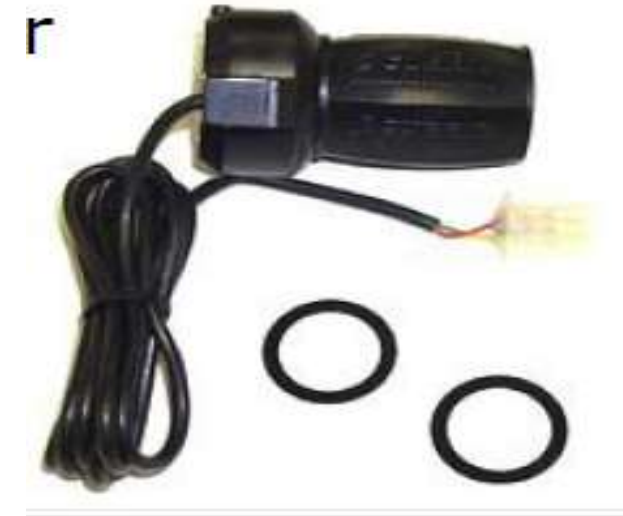

Throttle

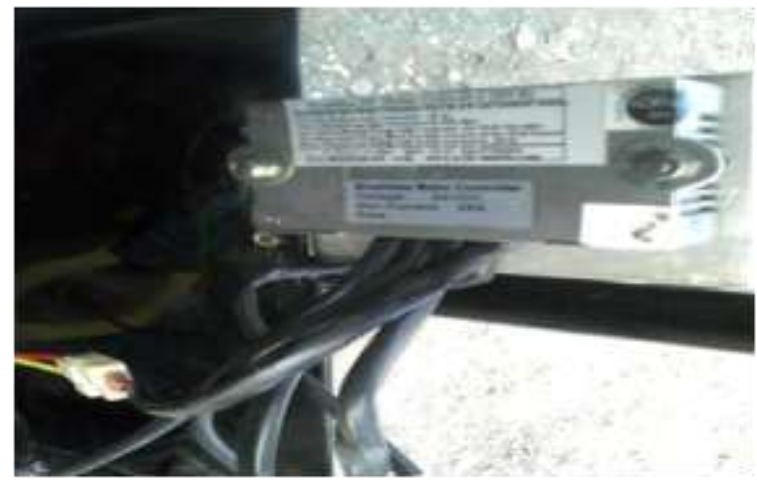

motor controller

\subsection{Design of shaft:-}

An electric power shaft transmits to 250 watt power at $300 \mathrm{rpm}$ to find out design of shaft with assuming suitable material.

\section{Given data-}

Power $=250$ watt $=0.25 \mathrm{kw}$

$\mathrm{N}=300 \mathrm{rpm}$

Step 1- Design of shaft for finding diameter:

Assuming material for shaft -

$\mathrm{SAE}=1030$ [Design data page no: 39]

Sut $=527$, Syt $=296$

Step 2- $\mathrm{T}=$ torque

$$
\begin{aligned}
& T=\frac{\Pi}{16 \mathrm{~T} \times \mathrm{d}^{3}} \\
& \mathrm{P}=\frac{2 \Pi \mathrm{NT}}{60} \\
& 0.25=\frac{2 \Pi \times 300 \times \mathrm{T}}{60000}
\end{aligned}
$$

$\mathrm{T}=7.96 \times \mathrm{KL} \quad$ Where $\mathrm{KL}$ is a load factor:-

$\mathrm{KL}=1.75$ [Design data book page no:-112]

$\mathrm{T}=5.96 \times 1.75$

$\mathrm{T}=13.93 \mathrm{~N}-\mathrm{M}$

$\mathrm{T}=13.93 \times 1000 \mathrm{~N}-\mathrm{MM}$

For solid shaft:-

$$
\begin{aligned}
& \text { Tmax } x<0.3 \text { sytOR } \quad T \max x<0.18 \\
& \begin{array}{ll}
=0.3 \times 296 & =0.18 \times 527 \\
=88.8 \mathrm{Mpa} & =94.86 \mathrm{Mpa}
\end{array}
\end{aligned}
$$

Consider minimum value of

$$
\text { Tmax }=88.8 \mathrm{~N} / \mathrm{mm}^{2} \quad \text { (Without keyway) }
$$




$$
\begin{gathered}
\text { Tmax }=88.8 \times 0.75 \\
\text { Tmax }=66.6 \mathbf{N} / \mathbf{m m}^{2} \\
\text { Torque }=\frac{\Pi}{16 \mathrm{~T} \times \mathrm{d}^{3}} \\
13.93 \times 1000= \\
d=10.21 \mathrm{~mm}
\end{gathered}
$$

(With keyway)

Considering bending stress develop on a shaft therefore diameter of shaft will be increased by $50 \%$

$$
\mathrm{d}=10.21 \pm 1.5
$$

$\mathrm{d}=15.32 \mathrm{~mm}$

$\mathrm{d}=16 \mathrm{~mm}$ (standard diameter for design data book page no:-182)

\section{$\mathrm{d}=16 \mathrm{~mm}$}

Therefore diameter of shaft is $16 \mathrm{~mm}$

\section{Design of solar beam radiation}

A Solar tricycle which is placed on wardha made of angle beam radiation On may 1 at 9.00am (local apparent time) the solar panel is located in Wardha $\left(28^{\circ} 35^{\prime} \mathrm{N} 7712 \mathrm{E}\right)$ It is tilt an angle of $36^{\circ}$ with horizontal and is pointing done in south For this $\mathrm{h}=0^{\circ}$ Where $\mathrm{h}=$ the surface incident angle on may $1, \mathrm{n}=121$.

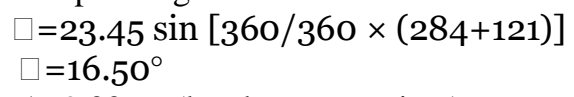

At 9.00am (local apparent time)

$\mathrm{W}=45^{\circ}$ Substituting in equation of inclination surface facing due south $\mathrm{h}=0^{\circ}$

$\operatorname{Cos} \mathrm{Q}=\sin \square(\sin \mathrm{Q}-\mathrm{B})+\cos \square(\mathrm{Q}-\mathrm{B})$

$\mathrm{Cos} Q=\sin 14.90^{\circ} \sin \left(28.58^{\circ}-36^{\circ}\right)+\left(\operatorname{Cos} 14.90^{\circ} \cos 45^{\circ} \cos \left(28.58^{\circ}-36^{\circ}\right)\right.$

$\mathrm{Cos} \mathrm{Q}=0.6444$

$\mathrm{Q}=48.90^{\circ}$

\section{Design of brake power}

The torque is measured by the tachometer device is $7.65 \mathrm{~N} / \mathrm{mm}$

$$
\begin{aligned}
B P & =\frac{2 \Pi \mathrm{NT}}{60} \\
B P & =\frac{2 \Pi \times 300 \times 7.65}{60} \\
B P & =240 \mathrm{w}
\end{aligned}
$$

Brake power of sooty $800 \mathrm{w}$ in normal condition in two wheeler but when two side wheels are attach then due to load these BP is also reduce.

Our BP is for single sitter handicapped person which is $240 \mathrm{w}$ and observed that is sufficient.

\subsection{Working}

Solar panels transfer energy to 12 volt deep cell batteries located on the bike's frame just below the chair. From there, a small brushless dc motor between the front wheel hubs powers the bike. The whole system is on a continuous feedback loop, enabling the bike to partially recharge while in use thus extending the bike's range. A dc motor located in front wheel is controlled by the speed controller and throttle. The rider can switch from pedal power to solar power easily, and when not in use, thes olar panels continue to recharge the batteries. The motor's maximum is $250 \mathrm{w}$.

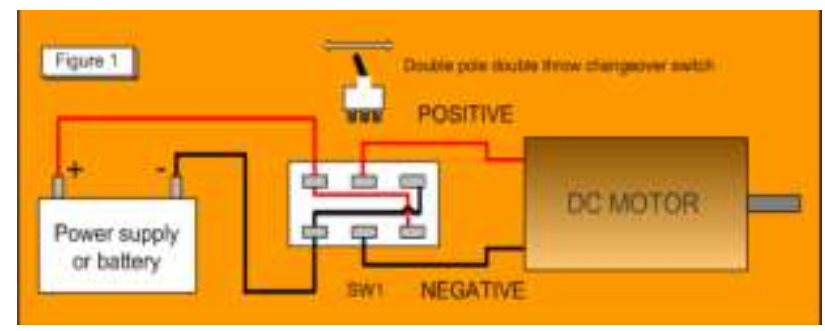

working diagram of solar tricycle 


\subsection{Result and discussion}

Diameter of the back wheel $=26$ inches

Diameter of the front wheel $=23$ inches

R.p.m of brushless dc motor $=300$

\section{Calculation}

$\begin{aligned} \mathrm{V} & =\mathrm{W}^{*} \mathrm{R} \\ \square & =2 \Pi \mathrm{n} \square 60=2 * \Pi * 300 \square 60=31,41 \mathrm{rad} / \mathrm{sec} .\end{aligned}$

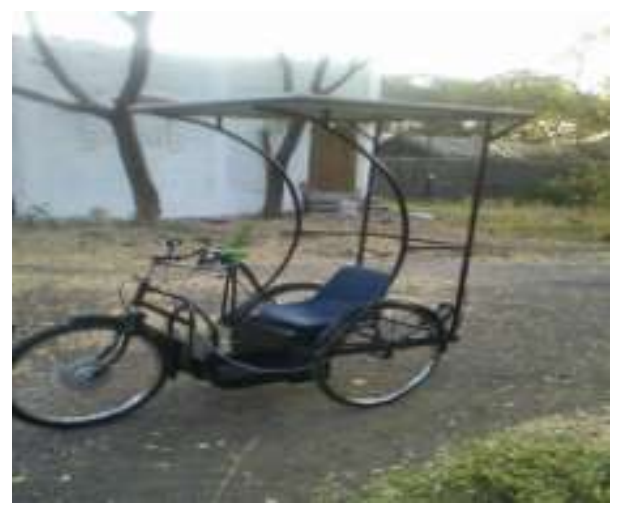

$\mathrm{V}=31.41 * 0.292=9.17 \mathrm{~m} / \mathrm{s}$

Finished solar tricycle

$\mathrm{V}=9.17 * 3600 / 1000=33.012 \mathrm{~km} / \mathrm{hr}$

V $\square \quad 33$ km/hr.

\section{Velocity diagram}
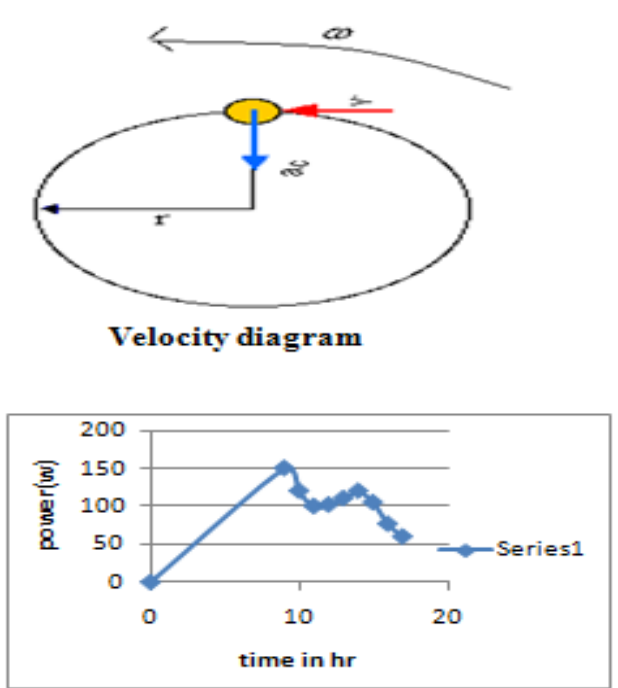

\begin{tabular}{|r|r|}
\hline \multicolumn{1}{|l|}{ time } & \multicolumn{1}{|l|}{ Power } \\
\hline 0 & 150 \\
\hline $9 \mathrm{am}$ & 120 \\
\hline $10 \mathrm{am}$ & 100 \\
\hline $11 \mathrm{am}$ & 102 \\
\hline $12 \mathrm{noon}$ & 110.4 \\
\hline $13 \mathrm{pm}$ & 120 \\
\hline $14 \mathrm{pm}$ & 105 \\
\hline $15 \mathrm{pm}$ & 76.8 \\
\hline $16 \mathrm{pm}$ & 60 \\
\hline $17 \mathrm{pm}$ & \\
\hline
\end{tabular}
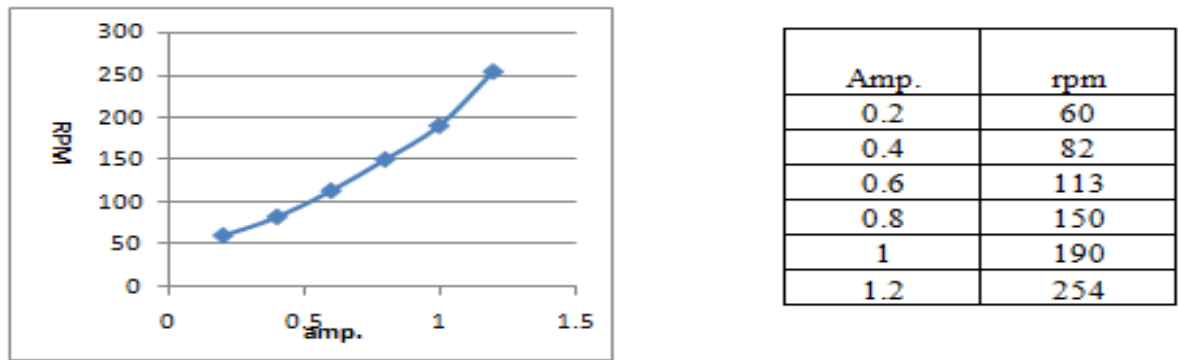

Relation between amps. \& rpm 


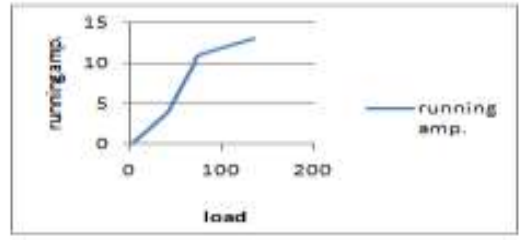

\begin{tabular}{|r|r|}
\hline \multicolumn{1}{|l|}{ load } & $\begin{array}{l}\text { Running } \\
\text { amp. }\end{array}$ \\
\hline 0 & 0 \\
\hline 40 & 4 \\
\hline 45 & 5 \\
\hline 50 & 6 \\
\hline 55 & 7 \\
\hline 60 & 8 \\
\hline 65 & 9 \\
\hline 70 & 10 \\
\hline 75 & 11 \\
\hline 135 & 13 \\
\hline
\end{tabular}

Relation betoveen cunning amps and load

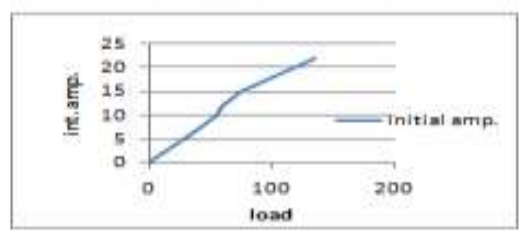

Relation between initial amp and no load

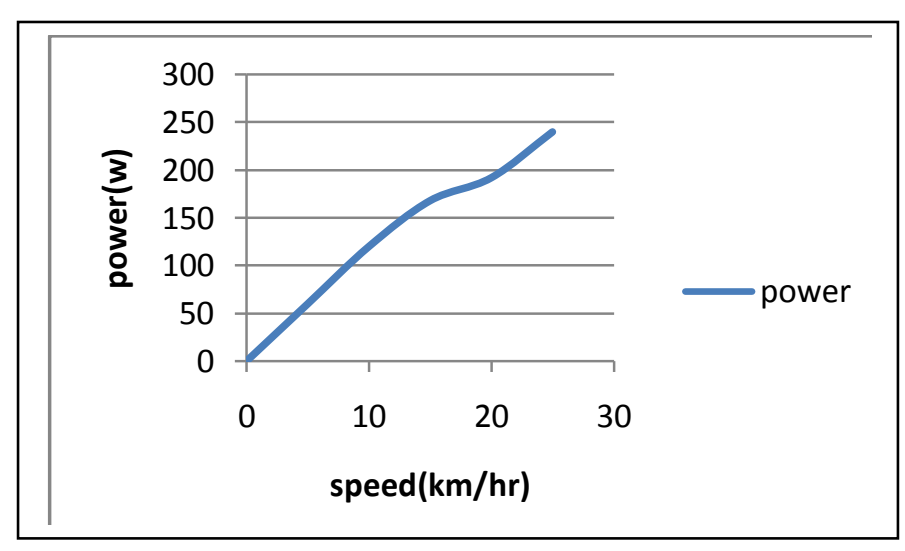

\begin{tabular}{|r|r|}
\hline load & initial amp. \\
\hline 0 & 0 \\
\hline 40 & 7 \\
\hline 45 & 8 \\
\hline 50 & 9 \\
\hline 55 & 10 \\
\hline 60 & 12 \\
\hline 65 & 13 \\
\hline 70 & 14 \\
\hline 75 & 15 \\
\hline 135 & 22 \\
\hline
\end{tabular}

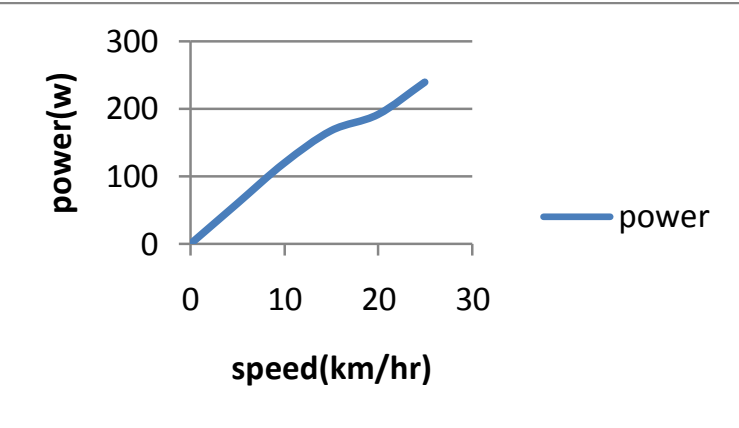

\begin{tabular}{|r|r|}
\hline speed $(\mathrm{km} / \mathrm{hr})$ & \multicolumn{1}{l|}{ power } \\
\hline 25 & 240 \\
\hline 20 & 192 \\
\hline 15 & 168 \\
\hline 10 & 120 \\
\hline 5 & 60 \\
\hline 0 & 0 \\
\hline
\end{tabular}

Relation between Power vs. speed

Table 1 Morphological analys is

\begin{tabular}{|l|l|}
\hline Body Support & $\begin{array}{l}\text { Chair, arm chair, plastic paddle, } \\
\text { back support, inclined chair. }\end{array}$ \\
\hline Structure & $\begin{array}{l}\text { Solar panel form and the position, } \\
\text { the bars for holding the solar } \\
\text { panel, space frame, }\end{array}$ \\
\hline Propulsion & $\begin{array}{l}\text { Wheels, multi chain wheels, sail, } \\
\text { fans, sweep, jet engine }\end{array}$ \\
\hline Speed Control & $\begin{array}{l}\text { Automatic manual, hand brake, } \\
\text { variable resistance, Gear box }\end{array}$ \\
\hline Direction & $\begin{array}{l}\text { Steering wheel, handlebar, } \\
\text { reverse, robs. }\end{array}$ \\
\hline Stability & $\begin{array}{l}\text { Two wheels, three wheels, four } \\
\text { wheels, solar panels location, } \\
\text { solar panel shape. }\end{array}$ \\
\hline Power Supply & $\begin{array}{l}\text { Electric battery, human paddling, } \\
\text { magnetic filed, solar energy, } \\
\text { nuclear energy, internal-external } \\
\text { combustion engine, wind energy. }\end{array}$ \\
\hline Accessories & $\begin{array}{l}\text { Horn, fan, glass, cd player, speed } \\
\text { indicator }\end{array}$ \\
\hline
\end{tabular}


Table no 2 Evaluation analysis

Note: $1=$ bad, 2 -not bad, $3=$ good, $4=$ very good, $5=$ =xcellent

\begin{tabular}{|l|l|l|l|l|l|}
\hline Sr. no. & Feature & Bicycle & Tricycle & Car & ATV \\
\hline $\mathbf{1}$ & Safety & 2 & 3 & 5 & 2 \\
\hline $\mathbf{2}$ & Stability & 2 & 3 & 5 & 4 \\
\hline $\mathbf{3}$ & Cost & 5 & 3 & 1 & 2 \\
\hline $\mathbf{4}$ & Maintenance & 5 & 4 & 1 & 3 \\
\hline $\mathbf{5}$ & $\begin{array}{l}\text { Commuter } \\
\text { acceptance }\end{array}$ & 3 & 2 & 5 & 1 \\
\hline $\mathbf{6}$ & Total & 17 & $\backslash 15$ & 17 & 12 \\
\hline
\end{tabular}

Table no 3 Comparison of solar vehicle and normal vehicle

\begin{tabular}{|l|l|l|l|}
\hline Sr no & & $\begin{array}{l}\text { solar } \\
\text { vehicle }\end{array}$ & $\begin{array}{l}\text { normal } \\
\text { vehicle }\end{array}$ \\
\hline 1 & Cost & high & low \\
\hline 2 & Human effort & Less & More \\
\hline 3 & Speed & More & Less \\
\hline 4 & Electricity & yes & no \\
\hline 5 & Handling & easy & Hard \\
\hline 6 & Comfort & good & bad \\
\hline 7 & $\begin{array}{l}\text { Fuel } \\
\text { alternative }\end{array}$ & yes & Not always \\
\hline 8 & Pollution & No & No \\
\hline
\end{tabular}

Table no 4 COST OF MATERIAL

\begin{tabular}{|l|l|l|l|l|}
\hline SR NO. & COMPONENT & Unit Cost & Quantity & Total Cost \\
\hline 1 & TRICYCLE & 2000 & 1 & 2000 \\
\hline 2 & Solar panel 12 & 15000 & 1 & 15000 \\
\hline 3 & Dc motor & 8000 & 1 & 8000 \\
\hline 4 & Motor Controller & 2500 & 1 & 2500 \\
\hline 5 & Wires & & & 200 \\
\hline 6 & Battery 24V 100A & 5000 & 2 & 5000 \\
\hline 7 & Fabrication & & & 2000 \\
\hline & Total & & & 34700 \\
\hline
\end{tabular}

\section{Advantages}

1. Solar energy creates absolutely no pollution. This is perhaps the most important advantage that makes solar energy so much more practical than oil. Oil burning releases harmful greenhouses gases, carcinogens and carbon dioxide into our precious air.

2. Solar energy is a completely renewable resource. This means that even when we cannot make use of the sun's power because of nighttime or cloudy and stormy days, we can always rely on the sun showing up the very next day as a constant and consistent power source.

3. Solar panels and solar lighting may seem quite expensive when you first purchase it, but in the long run you will find yourself saving quite a great deal of money. After all, it does not cost anything to harness the power of the sun. Unfortunately, paying for oil is an expensive prospect and the cost is still rising consistently. Why pay for expensive energy when you can harness it freely?

4. Solar powered panels and products are typically extremely easy to install. Wires, cords and power sources are not needed at all, making this an easy prospect to employ.

5. Solar power technology is improving consistently over time, as people begin to understand all of the benefits offered by this incredible technology. As our oil reserves decline, it is important for us to turn to alternative sources for energy.

6. Oil, which is what most people currently use to power their homes, is not a renewable resource. This means that as soon as the oil is gone, it is gone forever and we will no longer have power or energy. Very little maintenance is required to keep solar cells running. There are no moving parts in a solar cell, which makes it impossible to really hurt them. Solar cells tend to last a good long time with only an annual cleaning to worry about. 
7. Solar cells make absolutely no noise at all. They do not make a single peep while extracting useful energy from the sun. On the other hand, the giant machines utilized for pumping oil are extremely noisy and therefore very impractical.

8. Because an SPV has few moving parts, service requirements are less than for conventional cars.

9. Since there is no internal combustion engine and no combustion takes place, there are no emissions.

10. Electric vehicles are very quiet. Noise comes only from the electric motors

11. Because SPV energy is $100 \%$ solar derived, no refueling, in a generic sense, is required. SPV's rely on solar power, and the only requirement is that they must be operated in sunshine.

12. Added emissions are not produced by power plants, since SPV's do not rely on utility-generated electricity.

13. Efficient vehicles have traveled a mile on less energy than a 100-watt light bulb consumes in one hour. (For a gasoline-powered car to achieve comparable efficiency, it would need to get 500 miles per gallon.)

\section{Disadvantages:}

1. Initial purchase price is high.

2. Storage batteries will need to be replaced after about 3-5 years.

3. Can't carry more than one passenger.

4. Slow speed comparing with other ways of transportation

5. Although solar energy is an unlimited resource, it is not always available when it's needed - the sun must be shining.

6. SPV's that have a built-on PV array differ from conventional vehicles (and most electric vehicles) in size, weight, and shape. The car must be efficiently designed. Lightweight structural materials, such as aluminum or lightweight composites, and low friction components improve performance. They are usually built to carry very little - only one or two people.

7. Some SPV's use no batteries; others use lightweight silver-zinc batteries. These batteries are expensive and need to be recycled after only a few charging cycles. Nickel-metal-hydride batteries may last up to 100,000 miles, but significantly increase the weight of the vehicle. (Lithium ion battery use is possible, but very expensive.)

8. A large amount of surface area is needed on the car to be used solely for solar power PV cells. State-of-theart PV cells are only about 20 percent efficient.

9. The primary safety concern with the development of a prototype vehicle, or vehicle altered by hobbyists as the majority of SPVs are - is that of design and an ability to adequately test the vehicle. If meant for road use, the final design must be road worthy. Proper attention must be paid to all aspects of vehicle design, including steering, suspension, breaks, protection for the driver, proper seatbelts and seating, properly secured motors and batteries, and adequate chassis strength and durability. All prototypes and modified vehicles must be properly tested before operating on-road.

10. As with all electric vehicles, lethal levels of electricity may be present in the battery pack, so it should be treated with caution and respect

\section{Applications}

1. Travel for free with the power of the sun.

2. Provides free, 'green' transportation for short distances ( $<10$ miles), thus it must never plug into a wall socket, or emit any pollutants.

3. Charges while at work

4.Is cheap, simple, and low maintenance.

5. Draws attention to the practical

\section{Conclusion}

We can say our project can be a success considering the changes we had to make in the spring once we actually found out how the hybrid solar tricycle was for. We can achieve our five aims, and we believe that we have a system that will be effective in providing mobility for persons who have disabilities. One of the major lessons we have learned is that designing an appropriate technology is a huge challenge. Appropriate is more than just availability for replication, it considers longevity, reliability, and efficiency.

\subsection{Limitations}

- Initial purchase price is high.

- Storage batteries will need to be replaced after about 3-5 years.

- Can't tricycle more than one passenger.

- Slow speed comparing with other ways of transportation. 
- Although solar energy is an unlimited resource, it is not always available when it's needed — the sun must be shining.

- SPV's that have a built-on PV array differ from conventional vehicles (and most electric vehicles) in size, weight, and shape. The tricycle must be efficiently designed. Lightweight structural materials, such as aluminum or lightweight composites, and low friction components improve performance. They are usually built to tricycle very little - only one or one people.

- Some SPV's use no batteries; others use lightweight silver-zinc batteries. These batteries are expensive and need to be recycled after only a few charging cycles. Nickel-metal-hydride batteries may last up to 100,000 miles, but significantly increase the weight of the vehicle. (Lithium ion battery use is possible, but very expensive.)

- A large amount of surface area is needed on the tricycle to be used solely for solar power PV cells. State-ofthe-art PV cells are only about 20 percent efficient.

- The primary safety concern with the development of a prototype vehicle, or vehicle altered by hobbyists - as the majority of SPVs are - is that of design and an ability to adequately test the vehicle. If meant for road use, the final design must be road worthy. Proper attention must be paid to all aspects of vehicle design, including steering, suspension, breaks, protection for the driver, proper seatbelts and seating, properly secured motors and batteries, and adequate chassis strength and durability. All prototypes and modified vehicles must be properly tested before operating on-road.

- As with all electric vehicles, lethal levels of electricity may be present in the battery pack, so it should be treated with caution and respect.

\section{References}

[1] Theory of machine- Khurmi Gupta

[2] Solar energy by S.P. Sukhatme

[3] Principle of solar collection and storage by JK Nayak

[4] About photovoltaic cell by text book of Solar photovoltaic application text book- R. K. Pachuri

[5] Facts about solar energy by textbook of renewable energy in Sundarban- author by S.K. Chaudhri

[6] Literature review by Advance solar energy Conversion by M.A. Green author

[7] A text book of Electricity from sunlight by A.K. Paul author

[8] Permanent magnet synchronous and brushless d.c .motor drives by-R. Krishnan

[9] Photovoltaic system - James p. Dunlop

[10] Physics of solar cell-peter wifel

[11] Advanced solar energy-Martine green

[12] Principle of solar energy by Jan f.kreider

[13] About solar panel information by Solar energy handbook-Michel boxwell

[14] About power supply information taken by Electrical technology textbook by B.L. thereja

[15] http://www.nationalguild.com/zap/techreport.html

[16] http://www.analyticcycling.com/

[17] http://ieeexplore.iee.org 